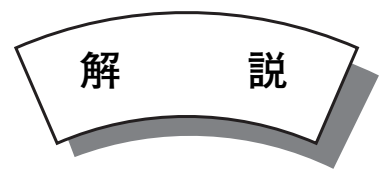

\title{
新しいレーザブレージング法によるセラミックスと金属の異材接合
}

\section{Dissimilar Joining of Ceramics and Metal by Novel Laser Brazing Process}

\author{
永塚公彬*・瀬知啓久**.中田一博* \\ Kimiaki NAGATSUKA, Yoshihisa SECHI and Kazuhiro NAKATA
}

Key Words: Laser Brazing, Graphite, Ceramics, Ag-Cu-Ti Filler Metal, WC-Co Alloy

\section{1.はじめに}

セラミックスは金属に比べ低密度、低熱膨張係数であり、 硬さ、耐熱性、耐食性および特殊な電磁気特性などを有し ているが、破壊勒性が低く、難加工性であるという特徵を 持っている。またセラミックスの製造方法としては焼結が 一般的であるが、大型や複雑な形状の製品は焼結が難しく、 一度焼結されると加工が難しく、大型になるほど体積効果 で強度の信頼性が低下するなどの欠点を持っている ${ }^{1,2)}$ 。一 方で、金属材料は加工性に優れ、機械加工が容易であり、 機械的性質や勒性に優れており、またセラミックスと比較 して安価なものが多いことから幅広く用いられている ${ }^{3,4)} 。$ そこでセラミックスの欠点を克服するために、金属と複合 化させ、それぞれの特徵的な機能を十分に活かす適材適所 な使い方が重要となる。セラミックスの具体的な応用分野 としては、その硬さや耐摩耗性に優れた特徵を活かした工 具や、熱膨張係数の低さや耐熱性から耐熱部材や、放熱用 部材などがあげられる ${ }^{1,2,5-8)}$ 。これらはいずれも、高価なセ ラミックスを適材適所に金属材料と異材接合することで、 製品の性能を低下させずに安価で強度の信頼性を維持して いる。また、近年では電子デバイス分野において、集積回 路の集積度が上がるなかで、セラミックスのパワーデバイ スとしての利用が盛んに行われており、セラミックスと金 属の異材接合の需要は益々高まるものと考えられる9

セラミックスと金属の接合方法としては、一般にろう付 が行われている。ろう付は種々の接合法の中でも、セラミッ クスと金属材料などの溶融溶接による接合が困難な異材接 合に適している 10-14)。ろう付にあたっては、セラミックス と溶融ろう材との濡れ性を改善するために、活性金属ろう 材を用いるか、あるいは何らかの表面処理をセラミックス の前処理として行う必要がある。活性金属ろう材を用いる
方法では、表面処理工程無しに直接接合を行うことが可能 となるものの、活性金属の酸化を抑制するために高真空に 排気可能な真空炉中で炉中ろう付が行われる。しかし、従 来の炉中ろう付では、部材全体を長時間にわたって加熱 ·

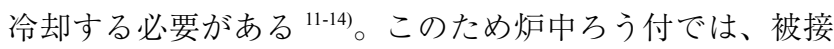
合材の材質劣化が生じること、厚膜の界面反応層が形成さ れて接合強度が低下すること、ならびにセラミックスと金 属の熱澎張係数の差に起因する大きな残留応力およびこれ らに起因する割れの発生などの問題が顕著となる。

\section{2.レーザを用いた新しいブレージング法}

\section{1 プロセスの特徴}

レーザブレージングとは、熱源にレーザを用いるろう付 方法であり、従来のろう付方法と同様に、ろう材をあら かじめろう付部に設置してレーザを照射する置きろう方式 と、ろう材を連続的に供給しながらレーザを照射する差し ろう方式がある。差しろう方式のレーザブレージングは、 これまでに金属材料同士の異材接合の組み合わせとして耐 熱合金のろう付やアルミニウムと鋼の異材接合などが検討 されている 15-17)。これに対し、セラミックスと金属の異材 接合法としては、Fig. 1 に示すような置きろう方式のレー ザブレージング法が著者らによって新しく提案されてお り、本稿ではこの置きろう方式の新しいレーザブレージン グ法（以下、単にレーザブレージング法と表記する）を紹 介する ${ }^{18-24)}$ 。

本レーザブレージング法においては、被接合材である金 属上にレーザを照射して、あらかじめ設置したろう材を 金属からの熱伝導によって溶融させる。活性金属乃う材の 酸化を抑制するために、雲囲気制御が可能な小型のチャン バー中で接合を行うが、従来の炉中ろう付に比べて、加熱 が局部的で、かつ加熱および冷却が短時間で行われること

*大阪大学接合科学研究所加工システム研究部門（† 567-0047 大阪府茨木市美穂ヶ丘 11-1）

Research Division of Materials Processing System, Joining and Welding Research Institute, Osaka University (11-1 Mihogaoka, Ibaraki, Osaka, 567-0047 Japan)

**鹿児島県工業技術センター 生産技術部（ $\bar{T} 899-5105$ 鹿児島県霧島市隼人町小田 1445-1）

Kagoshima Prefectural Institute of Industrial Technology (1445-1 Oda, Hayato-cho, Kirishima, Kagoshima, 899-5105 Japan) 


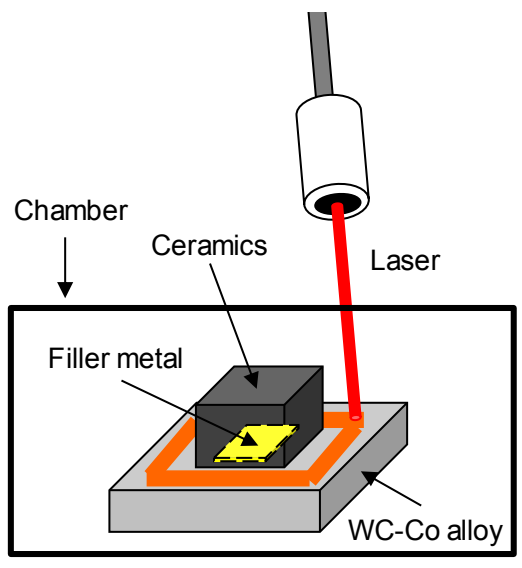

Fig. 1 Schematic illustration of laser brazing.

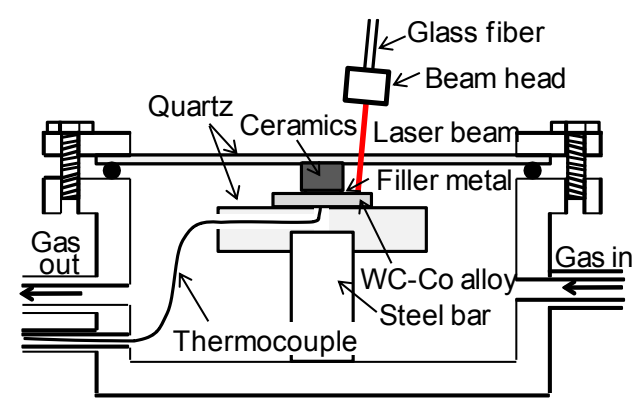

Fig. 2 Schematic illustration of laser brazing apparatus.

などから、炉中ろう付に必要な高真空排気装置を必要とせ ず、低真空排気後にArフロー中で接合を行うことが可能 である。こうしたことから、本レーザブレージング法の特 徵としては、

(1) 高真空排気が不要であること

(2) 部分ろう付が可能であること

(3) 加熱および冷却が短時間で行われ、ろう付能率が高い こと

（4）自動化が容易であること

(5) 界面反応層の成長を抑制できること

(6) セラミックス素材材質の劣化を抑制できること

などが挙げられる ${ }^{18-24)}$ 。また、レーザヘッド部または照射 部分を載せたステージを用いることでレーザの照射位置を 容易に制御できることから、1 バッチで多種類の製品の接 合を行うことも可能である。したがって、レーザブレー ジングをセラミックスと金属の異材接合に用いることによ り、炉中ろう付よりも高品質で簡便かつ高速な接合を行う ことが可能である。

しかし、セラミックス/ろう材の界面反応層の形成はセ ラミックスおよびろう材の構成原子の拡散および界面反応
Table 1 Laser brazing conditions.

\begin{tabular}{cc}
\hline Pulsed YAG average output & $0.134 \mathrm{~kW}$ \\
\hline Pulsed YAG wave length & $1064 \mathrm{~nm}$ \\
\hline CW LD output & $0.02 \mathrm{~kW}$ \\
\hline CW LD wave length & $808 \mathrm{~nm}$ \\
\hline Pulse frequency & $100 \mathrm{~Hz}$ \\
\hline Scanning time & $36 \mathrm{~s}$ \\
\hline Atmosphere & Ar flow $(5 \mathrm{~L} / \mathrm{min})$ \\
\hline
\end{tabular}

によって行われる。このため短時間の加熱および冷却によ るレーザブレージングにおいては、ろう材中の活性金属元 素の添加量がろう材とセラミックスの濡れ性、界面反応層 の形成および接合強度に及ぼす影響は大きい。そこで活性 金属である $\mathrm{Ti}$ の添加量を変化させたいくつかの試作ろう材 を用いて、Cのみからなる単純な黒鉛と、代表的なセラミッ クスとして炭化ケイ素およびサイアロンを対象として、基 材超硬合金とのレーザブレージングによる異材接合を行っ た事例を紹介する。

\section{2 プロセスの概要および装置}

レーザブレージング装置の模式図を Fig. 2 に示す。試料 はセラミックスと超硬合金を上下に配置し、その間の接合 継手面にろう材を挟んだ状態で、真空チャンバー内に設置 し、試料の上部を透明石英ガラス（厚さ $2 \mathrm{~mm}$ ) で押さえ た。この透明石英ガラスは、試料を固定する機能を兼ねて おり、レーザはこれを透過して照射される。この状態でチャ ンバー内をロータリポンプを用いて排気し、純度 $99.999 \%$ の Ar ガスにより置換する作業を 5 回繰り返し、最終的に $\operatorname{Ar}$ ガス流量 5 L/min にてろう付した。レーザブレージング の条件を Table 1 に示す。レーザにはパルス YAG レーザ と半導体レーザのハイブリッドレーザを用い、これらを透 明石英ガラスを通じて、超硬合金の上部に対し、85の入 射角度でセラミックスの周囲を $36 \mathrm{~s}$ 照射した。また、超硬 合金板の裏側から接合界面直近 $(0.2 \mathrm{~mm})$ まで開けた穴に $\mathrm{R}$ 型熱電対を挿入して、レーザブレージング中の温度変化を 測定した。

ろう材の化学組成を Table 2 に示す。ろう材には、共晶 組成の $\mathrm{Ag}-\mathrm{Cu}$ 合金に対し Ti を 0 から 2.8 mass\% まで添加し、 真空溶解炉にて溶製し圧延した 8 種類のろう材箔 $(3 \mathrm{~mm} \times$ $3 \mathrm{~mm} \times 0.1 \mathrm{~mm})$ を用いた。その寸法は加熱によって溶けた ろう材が接合部からはみ出てフィレットを形成しないよう に決定した。なおろう材組織は、Ti 添加量が少ない場合 は $\mathrm{Ag}$ および $\mathrm{Cu}$ の 2 相組織であり、 $\mathrm{Ti}$ 添加量が 1.3 mass\% 以上では $\mathrm{Ag}$ および $\mathrm{Cu}$ の 2 相組織に加えて塊状の粗大な $\mathrm{Cu}_{3} \mathrm{Ti}$ が認められた。 
Table 2 Chemical composition of filler metals.

\begin{tabular}{cccc}
\hline No. & $\mathrm{Ag}$ & $\mathrm{Cu}$ & $\mathrm{Ti}$ \\
\hline 1 & 72.0 & 28.0 & 0 \\
\hline 2 & 71.5 & 28.2 & 0.3 \\
\hline 3 & 71.5 & 28.1 & 0.4 \\
\hline 4 & 71.2 & 27.9 & 0.9 \\
\hline 5 & 70.9 & 27.8 & 1.3 \\
\hline 6 & 70.2 & 28.1 & 1.7 \\
\hline 7 & 70.2 & 27.5 & 2.3 \\
\hline 8 & 69.6 & 27.6 & 2.8 \\
\hline
\end{tabular}

供試材には、セラミックスとして黒鉛 (IG-11 > 99.9 mass $\% \mathrm{C})$ 、炭化ケイ素 $(\mathrm{RE}-\mathrm{SiC}>99 \mathrm{mass} \% \mathrm{SiC})$ およびサイ アロン $\left(\mathrm{SAN}-2>90 \mathrm{mass} \% \mathrm{Si}_{3} \mathrm{~N}_{4}\right)$ のブロック $(5 \mathrm{~mm} \times 5 \mathrm{~mm}$ $\times 3.5 \mathrm{~mm})$ 、ならびに基材金属としては ISO K10 相当の超硬 合金(WC-Co 合金)の板 $(10 \mathrm{~mm} \times 10 \mathrm{~mm} \times 2 \mathrm{~mm})$ を用いた。 ろう付に先立ち、これらの供試材およびろう材はアセトン を用いて 10 分間超音波洗浄した後、乾燥させた。

\section{3. 代表的な組み合わせ適用例}

3.1 黒鉛と超硬合金の異材レーザブレージング

3.1.1 レーザ加熱による温度変化および接合体の外観

Fig. 3 にレーザブレージング中のろう付部近傍の超硬合 金の温度変化の代表例を示す。超硬合金の温度はレーザ照 射中（36 s 間）に急激に上昇し、ろう材の融点（約 $1073 \mathrm{~K}$ ) を超える $1115 \mathrm{~K}$ に到達した。レーザ照射終了後は、数秒 でろう材の融点以下に冷却された。Fig. 4 に黒鉛／超硬合 金接合体の外観写真を示す。Ti 無添加のろう材を使用した 場合には、超硬合金とろう材は接合されたものの、黒鉛と ろう材は接合されなかった。一方、 Ti 添加量 $0.3 \mathrm{mass} \%$ 以 上のろう材を使用した場合には接合体が形成された。黑鉛 以外のセラミックス／超硬合金の組み合わせにおいても同 様の結果であった。これは活性金属として添加した Ti が黒 鉛やセラミックスと溶融ろう材の濡れ性を改善するととも に、接合界面において反応生成物である界面反応層を形成 したためと考えられる。また、ろう付に起因する外観上の 割れはいずれの接合体においても観察されなかった。

\section{1 .2 万う付界面の組織および微細構造}

Fig. 5 に Ti 添加量 $0.4 、 1.7$ および 2.8 mass\%のろう材を 用いた接合体断面における黒鉛とろう材界面の SEM 二次 電子線像 $(\mathrm{SEI}) 、$ および $\mathrm{C} 、 \mathrm{Ag} 、 \mathrm{Cu}$ および $\mathrm{Ti}$ の元素マッピ ングを示す。黒鉛とろう材の界面には、いずれの Ti 添加量 においても界面反応層の形成が認められた。黒鉛母材から は C、ろう材部からは $\mathrm{Ag}$ および $\mathrm{Cu}$ がそれぞれの主要構成

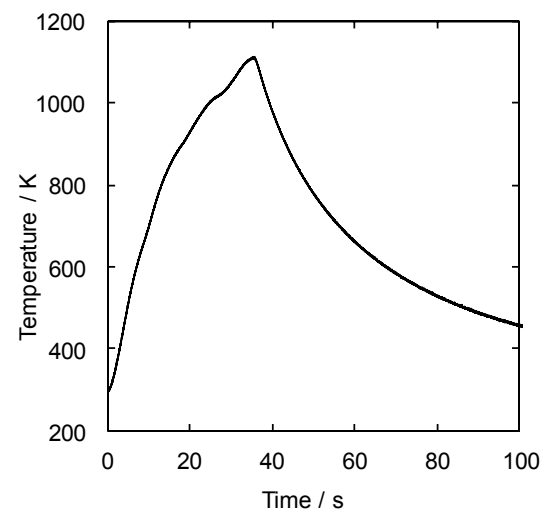

Fig. 3 Typical temperature profile during laser brazing.

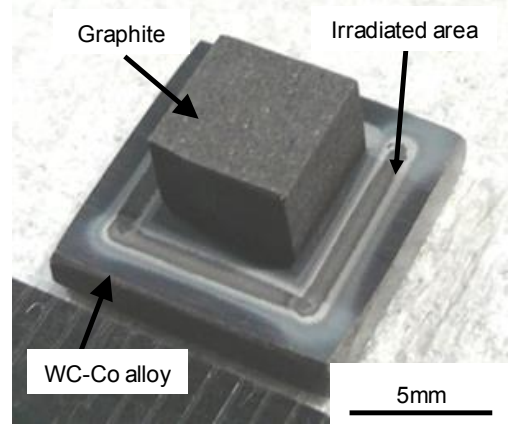

Fig. 4 Appearance of laser brazed joint of graphite/WC-Co alloy.

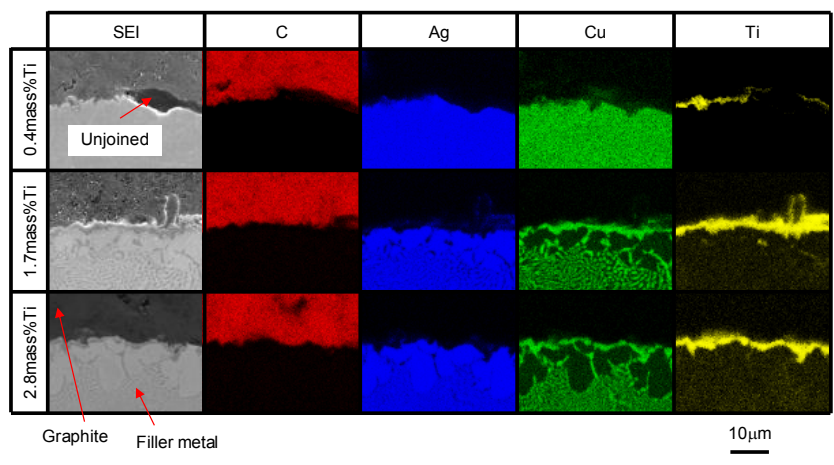

Fig. 5 Secondary electron images (SEI) and element distributions of laser brazed joint of graphite/0.4, 1.7 and 2.8 mass $\%$ Ti filler metal.

元素として強く検出された。活性金属として添加した Ti は ろう材内部からは検出されず、界面に形成された界面反応 層からのみ強く検出され、 $\mathrm{Ti}$ 添加量 $1.7 \mathrm{mass} \%$ 以上では、 $\mathrm{Ti}$ 濃化部には $\mathrm{Cu}$ が共存していた。この $\mathrm{Ti}$ および $\mathrm{Cu}$ の濃 化部のろう材側には、 $\mathrm{Cu}$ をほとんど含まない $\mathrm{Ag}$ の粗粒域 が認められた。Ti はろう付による加熱および冷却過程で界 


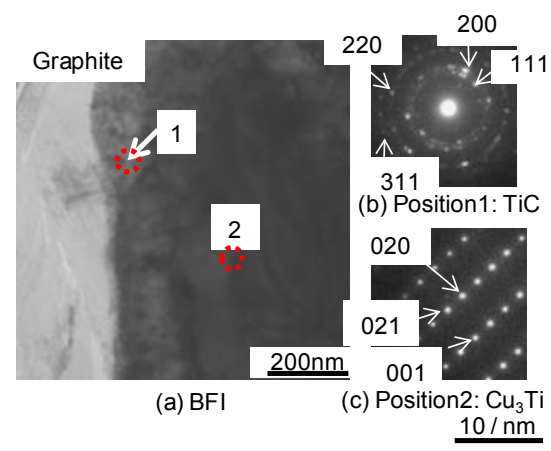

Fig. 6 (a) TEM bright field image(BFI) and selected area diffraction patterns at (b) position 1, (c) position 2 in BFI.

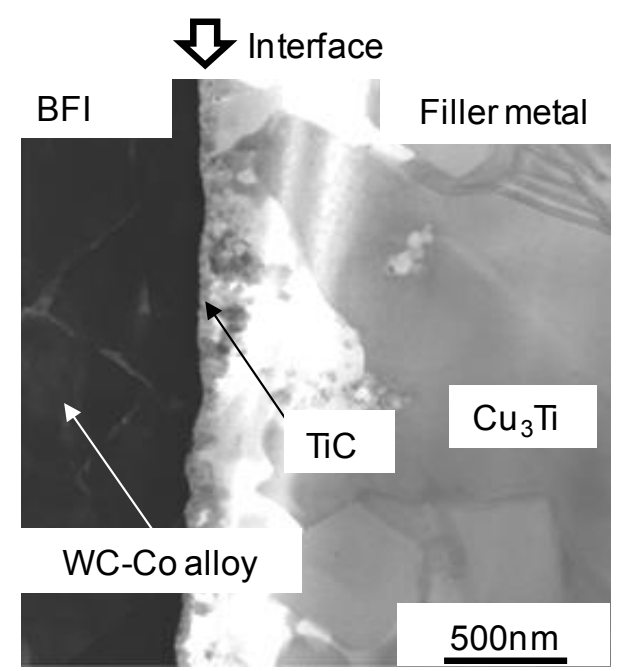

Fig. 7 BFI and detected phases at the interface of WC-Co alloy/1.7 mass\%Ti filler metal.

面に界面反応層を形成して濃化したと考えられる。これら の界面反応層の厚さは、ろう材中の $\mathrm{Ti}$ 添加量の増加ととも に厚くなった。また、Ti 添加量 1.7 mass\% 以上では Ti 濃化 層が連続的に形成されているのに対して、0.4 mass\%のろ う材では Ti 濃化層が不連続であり、黒鉛とろう材との接合 界面に挹いて Ti 濃化が認められない未接合部が存在した。 このような Ti 濃化層の形成および未接合領域の存在につい ては、黒鉛以外のセラミックス/超硬合金接合体の組み合 わせに㧍いても同様の結果が得られた。

Fig. 6 に Ti 添加量 1.7 mass\%のろう材を用いた場合の黒 鉛とろう材の界面組織の TEM 明視野像 (BFI) 㧍よび明視 野像中の position 1 および position 2 における制限視野電子 線回折の結果を示す。黒鉛とろう材の界面には黒鉛側から TiC、 $\mathrm{Cu}_{3} \mathrm{Ti}$ が界面反応層として形成された。ろう材中の $\mathrm{Ti}$ は、黒鉛の主成分である C と高い親和力を有することから、 Ti はろう材と黒鉛の界面に拡散し、これらの元素と反応し

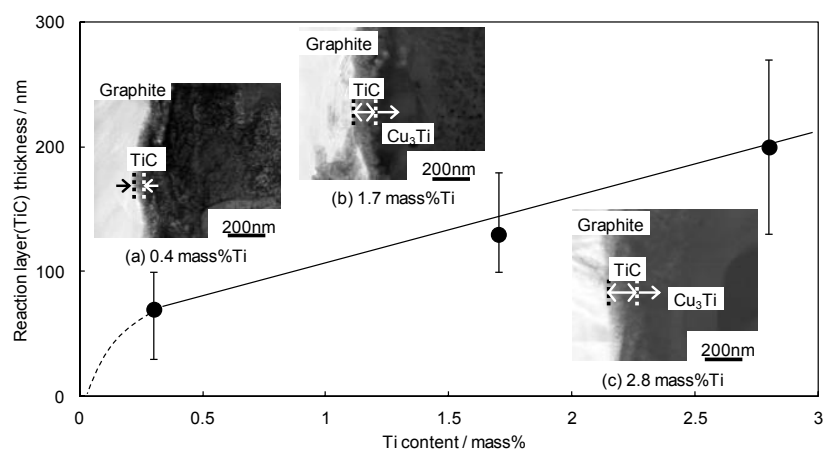

Fig. 8 Relation between Ti content and reaction layer (TiC) thickness, and BFI at the interface of graphite/0.4, 1.7 and 2.8 mass $\%$ Ti filler metal.

て薄い化合物層を形成したと考えられる。また、黒鉛と Ti の反応による $\mathrm{TiC}$ の生成については、1102 Kに扔いて $\mathrm{TiC}$ の生成自由エネルギーは $\mathrm{Ti}+\mathrm{C} \rightarrow \mathrm{TiC}$ の反応によって-170 $\mathrm{kJ} / \mathrm{mol}$ と負の值を示すことが熱力学的に説明される ${ }^{25)}$

また、Fig. 7 に Ti 添加量 1.7 mass\%のろう材を用いた 場合の超硬合金とろう材の界面組織の TEM 明視野像捛よ び制限視野電子線回折によって同定された界面反応層を示 す。超硬合金とろう材の界面に执いては、ろう材中の Ti と

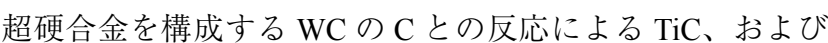
黑鉛界面側と同様の $\mathrm{Cu}_{3} \mathrm{Ti}$ 層から形成されており、超硬合 金とろう材は主にこれらの界面反応層を介して接合されて いた。

次に、黒鉛/ろう材界面反応層の形成相に及ぼす $\mathrm{Ti}$ 添 加量の影響を Fig. 8 に示す。Ti 添加量と界面反応層である $\mathrm{TiC}$ の厚さの関係を示したものであり、また界面反応層の 明視野像も合わせて図中に示す。いずれの Ti 添加量でも界 面反応層が認められ、 $\mathrm{Ti}$ 添加量にかかわらず同種の $\mathrm{Ti}$ 系化 合物であった。しかし、その形態抄よび厚さには Ti 添加量 による差異が認められた。すなわち、Ti 添加量 $1.7 \mathrm{mass} \%$ 以上では、これらの界面反応層が連続的に形成されている が、すでに Fig. 5 でも述べたように Ti 添加量 0.4 mass\% で は、反応層が形成されていない部分も存在した。そして Ti 添加量の増加にともなって、界面反応層として形成された TiC は厚くなる傾向を示した。

3.1.3 接合体のろう付継手強度特性

Fig. 9 に黒鉛と超硬合金を Ti 添加量の異なるろう材を 用いて接合したろう付継手のせん断強度を示す。Ti 添加量 0.3 mass\% では、接合は可能であったものの接合強度が低 く、せん断試験を行うのが困難であった。Ti 添加量 0.4 か ら 1.7 mass\% までの範囲においては、Ti 添加量の増加にと もなってせん断強度は増加し、 $1.7 \mathrm{mass} \%$ 以上では、約 14 MPa に飽和する傾向を示した。Fig. 10 に黒鉛と超硬合金 を Ti 添加量 0.4 および 1.7 mass\% で接合した接合体のせん 


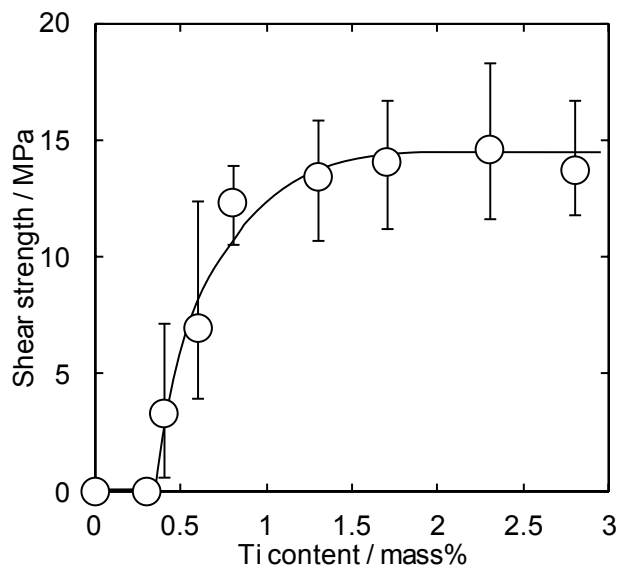

Fig. 9 Effect of Ti content on shear strength of brazed joint of graphite/ WC-Co alloy.

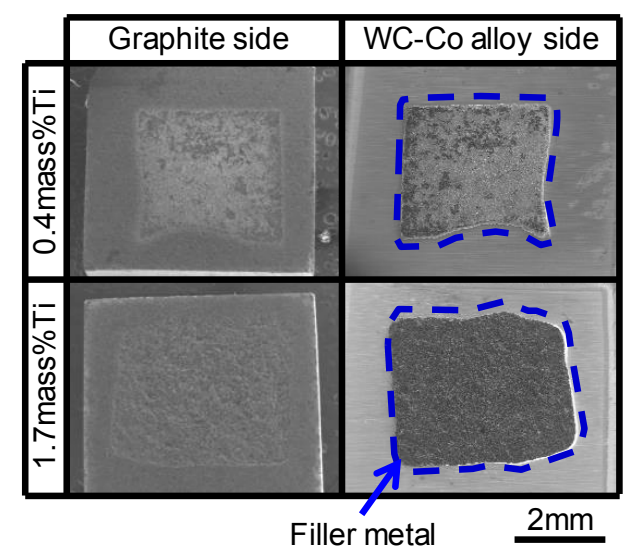

Fig. 10 SEI of fractured surface of brazed joints on graphite and WC-Co alloy sides using 0.4 and 1.7 mass $\%$ Ti.

断試験後の、黒鉛側および超硬合金側の破断面の SEM 観 察結果を示す。それぞれ黒鉛側と超硬合金側は紙面谷折の マッチング破断面である。いずれの Ti 添加量でも、図中 破線で示すようにろう材は超硬合金上に存在し、黒鉛側に は存在していなかった。また、ろう材が存在している領域 に注目すると、黒色部は黒鉛が母材破断して付着している 領域であり、Ti 添加量 1.7 mass\% ではろう材全面に黒鉛が 付着していることから破断形態としては黒鉛の母材破断で あることが分かる。一方、Ti 添加量 0.4 mass\% では黒鉛が 付着していない領域が認められることから母材破断と界面 破断が混合していた。ここで界面破断部は、界面反応層が 形成されていない未接合領域であると考えられる。次に、 Fig. 11 に超硬合金上のろう材部に存在している黒鉛の付着 面積率とせん断強度の関係を示す。せん断強度は、ろう材 上への黒鉛の付着面積率（黒鉛母材破断率）に応じて増加 する傾向を示した。データの変動幅が大きいのは、黒鉛母

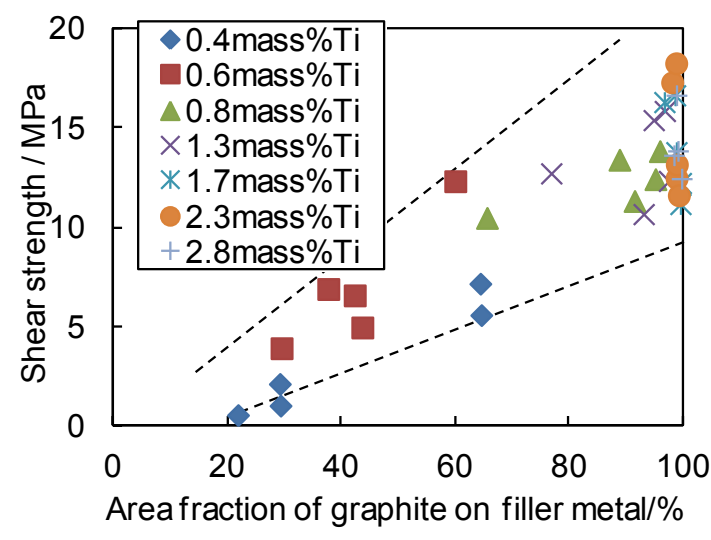

Fig. 11 Relation between area fraction of the fractured surface of graphite on filler metal and shear strength.

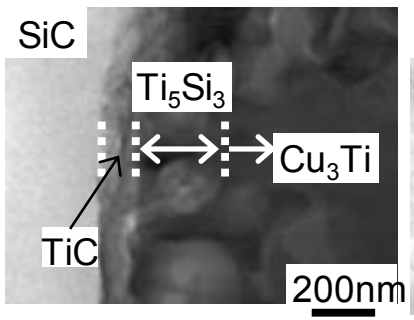

(a) Silicon carbide

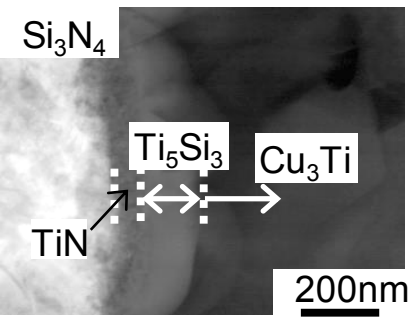

(b) Sialon
Fig. 12 BFI and detected phases at the interface of (a) silicon carbide and (b) Sialon/1.7 mass\%Ti filler metal.

材強度のばらつきと考えられる。これらの結果より、0.4か ら 1.7 mass\%において Ti 添加量の増加にともなってせん断 強度が向上する理由としては、 $\mathrm{Ti}$ 添加量の増加にともなっ て黒鉛とろう材の界面に界面反応層が連続的に形成され未 接合領域が減少し、黒鉛母材破断率が上昇してせん断強 度は上昇したと考えられる。また、Y. Zhu ら ${ }^{13)}$ は、Ag-28 mass $\% \mathrm{Cu}-1.8$ mass $\% \mathrm{Ti}$ 系活性ろう材を用いて、ろう付温度 1123 から $1223 \mathrm{~K}$ 、万う付時間 5 から $60 \mathrm{~min}$ にて黒鉛と銅 の炉中ろう接合体を作製し、接合体のせん断強度は 8 から $17 \mathrm{MPa}$ であり、いずれも黒鉛で母材破断が生じたと報告し ている。Y. Zhu らが用いたろう材と本研究における最も Ti 添加量が近い Ti 添加量 1.7 mass\%ののう材を用いた場合の、 せん断強度は 12 から $17 \mathrm{MPa}$ であることから、レーザブレー ジングによる短時間の加熱においても、炉中ろう付と同様 のせん断強度が得られることが明らかとなった。

3.2 炭化ケイ素およびサイアロンと超硬合金の異材レーザ ブレージング

\subsection{1 接合界面の微細構造}

Fig. 12 に Ti 添加量 1.7 mass\% のろう材を用いた場合の 炭化ケイ素およびサイアロンとろう材の界面の TEM 明視 
野像を示す。いずれも黒鉛の場合と同様に界面に界面反応 層が認められ、炭化ケイ素の場合では炭化ケイ素側から、 $\mathrm{TiC} 、 \mathrm{Ti}_{5} \mathrm{Si}_{3}$ および $\mathrm{Cu}_{3} \mathrm{Ti}$ が、サイアロンの場合ではサイア ロン側から $\mathrm{TiN} 、 \mathrm{Ti}_{5} \mathrm{Si}_{3}$ および $\mathrm{Cu}_{3} \mathrm{Ti}$ が形成された。これら の界面反応層の形成メカニズムとしては、黒鉛の場合と同 様であると考えられる。また、これらの界面反応層の厚さ は、ろう材中の $\mathrm{Ti}$ 添加量の増加にともなって厚くなった。 本稿で使用した 90 mass\% 以上が $\mathrm{Si}_{3} \mathrm{~N}_{4}$ で構成されるサイア ロンの接合体について、TiN および $\mathrm{Ti}_{5} \mathrm{Si}_{3}$ 層の厚さは、 $\mathrm{Ti}$ 添加量が 1.7 mass\%のろう材を用いてレーザブレージング によりろう付した場合は $200 \mathrm{~nm}$ 程度であった。一方、J.Zhang らによる Ag-26.88 mass\%Cu-3.99 mass\%Ti ろう材を用いた $\mathrm{Si}_{3} \mathrm{~N}_{4}$ 同士の炉中ろう付による場合では、 $\mathrm{TiN}$ および $\mathrm{Ti}_{5} \mathrm{Si}_{3}$ からなる界面反応層の厚さは約 $4.7 \mu \mathrm{m}$ と報告 ${ }^{14)}$ されてい る。彼らが行った炉中ろう付では、 $0.33 \mathrm{~K} / \mathrm{s}$ の加熱速度で $573 \mathrm{~K}$ まで加熱して 10 分保持後、 $0.17 \mathrm{~K} / \mathrm{s}$ の加熱速度でろ う付温度である $1173 \mathrm{~K}$ まで加熱して、その温度で 10 分保 持した後、 $0.083 \mathrm{~K} / \mathrm{s}$ の冷却速度で冷却するという熱履歴を 接合試料に与えている。また、彼らの報告では $\mathrm{Cu}_{3} \mathrm{Ti}$ 層や、 脱 $\mathrm{Cu}$ 層は認められていない。すなわち、万う付温度が高く、 かつろう付時間が十分に長いため、溶融ろう材中の Ti は すべて $\mathrm{TiN}$ および $\mathrm{Ti}_{5} \mathrm{Si}_{3}$ として反応したものと考えられる。 一方、レーザブレージングを用いた場合では、TiN および $\mathrm{Ti}_{5} \mathrm{Si}_{3}$ 層の厚さが炉中ろう付と比較して極めて薄い。この 理由として Ti の添加量や最大到達温度が異なることも挙げ られるが、主たる原因は加熱および拎却の時間がレーザブ レージングでは炉中ろう付と比べて著しく短いためにろう 付時の接合界面での元素の拡散距離が短くなり、これらの 層の成長が抑制されたと考えられる。すなわち、ろう付中 にサイアロンと反応して $\mathrm{TiN}$ および $\mathrm{Ti}_{5} \mathrm{Si}_{3}$ とならなかった 未反応の $\mathrm{Ti}$ は、ろう材中の $\mathrm{Cu}$ と反応して $\mathrm{Cu}_{3} \mathrm{Ti}$ 化合物層 を形成し、さらに $\mathrm{Cu}$ が $\mathrm{Ti}$ と反応した結果、界面近傍のろ う材中で $\mathrm{Cu}$ の濃度が低下して、脱 $\mathrm{Cu}$ 層が形成されたと考 えられる。

\section{2 .2 接合体のろう付継手強度特性}

炭化ケイ素およびサイアロンと超硬合金を Ti 添加量の異 なるろう材を用いて接合したろう付継手のせん断強度を黒 鉛のデータと合わせて Fig. 13 に示す。いずれも Ti 0.3 mass $\%$ 以上添加することでろう材を介して超硬合金との接 合が可能となり、Ti 添加量が低いろう材では、 Ti 添加量の 増加にともなってせん断強度は増加した。そして炭化ケイ 素では Ti 添加量 2.3 mass\%、サイアロンでは Ti 添加量 1.7 mass\% でせん断強度は最大となり、それ以上の Ti 添加量で はせん断強度は低下した。

Fig. 14 に炭化ケイ素を Ti 添加量 $0.4 、 1.7$ および 2.8 mass\%のろう材を用いて接合した接合体におけるせん断試 験後の超硬合金側の破断面の SEM-EDS 観察結果を示す。 いずれの Ti 添加量でも、ろう材は超硬合金側の破断面上に

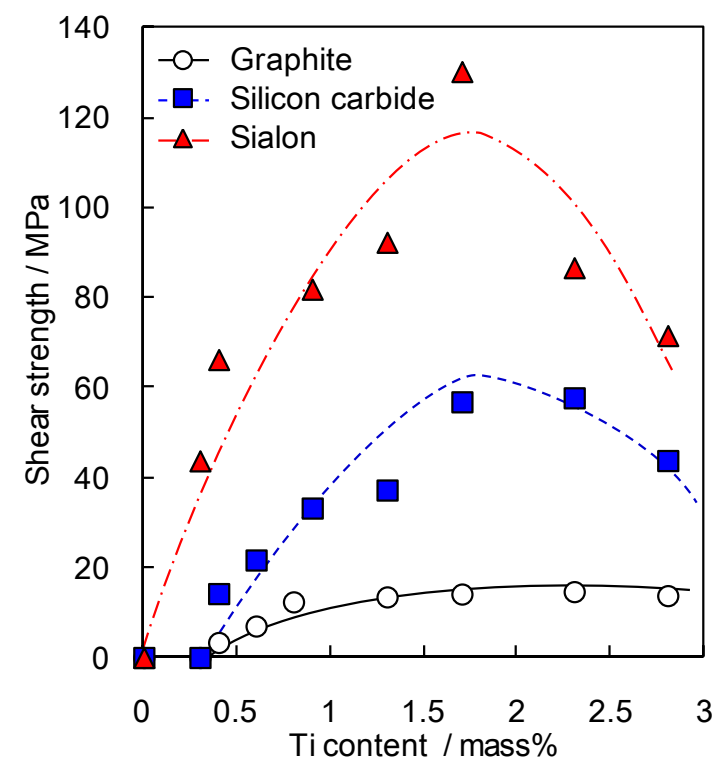

Fig. 13 Effect of Ti content on shear strength of brazed joint of graphite, silicon carbide and Sialon/WC-Co alloy.

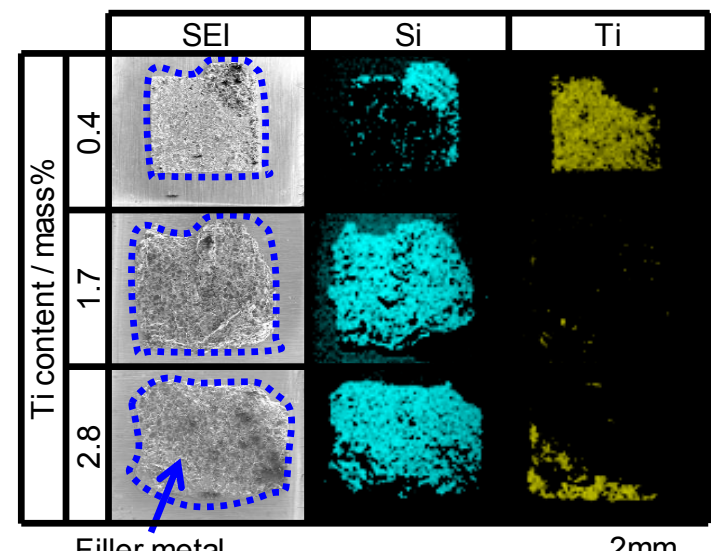

Filler metal

$2 \mathrm{~mm}$

Fig. 14 SEI and element distributions of Si and Ti of fractured surface of brazed joints on silicon carbide side using $0.4,1.7$ and 2.8 mass $\%$ Ti.

存在していた。Ti 添加量 0.4 mass\% でのろう材上には、ろ う材成分である $\mathrm{Ag} 、 \mathrm{Cu}$ および $\mathrm{Ti}$ が検出された領域と炭化 ケイ素の成分である Si が検出された領域が認められた。こ れらはそれぞれ界面破断部と炭化ケイ素の母材破断部であ る。Ti 添加量 1.7 mass\% では、ろう材上においても、ろう 材の成分である $\mathrm{Ag} 、 \mathrm{Cu}$ および $\mathrm{Ti}$ はほとんど検出されず、 全面に Si が存在していた。これは接合体がほぼ炭化ケイ素 母材破断であることを示している。これに対して、Ti 添加 量 $2.8 \mathrm{mass} \%$ では、ろう材上に、明確な $\mathrm{Ti}$ の存在領域が認 められ、一部で界面破断を呈したことを示している。 


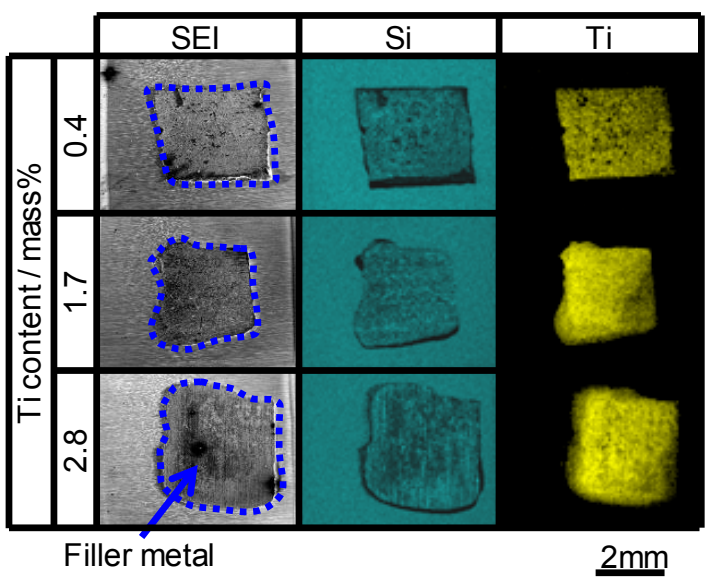

Fig. 15 SEI and element distributions of Si and Ti of fractured surface of brazed joints on Sialon side using $0.4,1.7$ and 2.8 mass\%Ti.

次に、Fig. 15 にサイアロンを Ti 添加量 $0.4 、 1.7$ および 2.8 mass\%のろう材を用いて接合した接合体のせん断試験後の 超硬合金側破断面の SEM-EDS 観察結果を示す。サイアロ ンの接合体においても、ろう材は超硬合金側の破断面に存 在していた。Ti 添加量によらず、いずれのろう材でも、ろ う材上から Ti が検出されたことから主としてサイアロンと ろう材の界面反応層中で破断したことが示唆される。さら に、X 線回折試験の結果より、炭化ケイ素およびサイアロ ン側破断面からは $\mathrm{Ti}_{5} \mathrm{Si}_{3}$ 、超硬合金側破断面から $\mathrm{Ti}_{5} \mathrm{Si}_{3}$ およ び $\mathrm{Cu}_{3} \mathrm{Ti}$ がそれぞれ検出されていることから、界面破断部 位は主として $\mathrm{Ti}_{5} \mathrm{Si}_{3}$ 層であると考えられる。

Fig. 16 に Ti 添加量による界面組織および推定される破 断経路の変化を模式図として示す。黒鉛、炭化ケイ素、サ イアロンの接合体について、それぞれ Ti 添加量が (a) 少な いろう材（Ti 添加量の増加にともなってせん断強度が向 上)、(b) 適正なろう材（せん断強度がもっとも高くなる）、 および (c) 過剩なろう材（Ti 添加量の増加にともなってせ ん断強度が低下）である。Ti 添加量が適正值以下では、そ れぞれのセラミックスとろう材の界面に未接合界面が存在 することから、破断は未接合界面に沿って生じ、Ti 添加 量の増加にともなって界面反応層が連続的に形成され、未 接合領域が減少する結果、接合強度は向上する。界面反応 層が形成されている領域については、炭化ケイ素接合体で は前述の黒鉛の場合と同様に、炭化ケイ素母材破断となり $\mathrm{Ti}$ 添加量の増加にともなって母材破断率が増加して適正值 ( Ti 添加量が 2.3 mass\%) で最大となる。 Ti 添加量がそれ以 上の過利な場合は母材破断率が低下して接合強度も低下す る。そしてサイアロン接合体では、サイアロンの母材強度 が高いことから、いずれの Ti 添加量においても主として界 面破断を呈する。

炭化ケイ素およびサイアロン接合体において、Ti 添加量

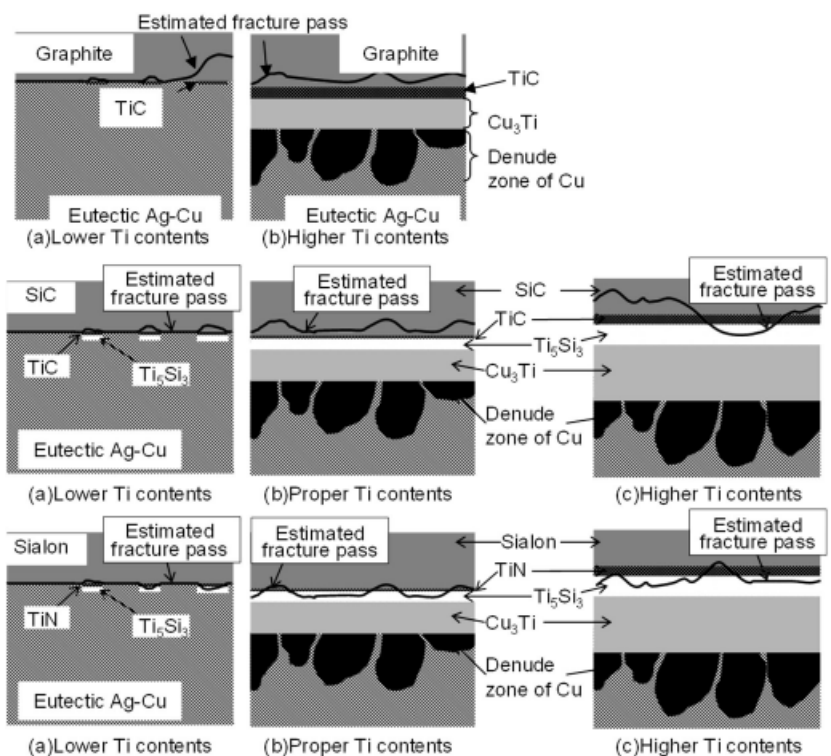

Fig. 16 Schematic illustrations of interface structure of laser brazed joint of graphite, silicon carbide and Sialon/WC-Co alloy, and estimated fracture pass for different levels of Ti content namely (a) lower, (b) proper and (c) higher contents.

が十分に多い場合に、Ti 添加量の増加とともにせん断強度 が低下した理由は、界面反応層が厚膜化したことによると 考えられる。界面反応層厚さが厚くなることで強度が低下 する理由は、明確には解明されていないが、界面反応層と して形成された $\mathrm{TiC} 、 \mathrm{TiN} 、 \mathrm{Ti}_{5} \mathrm{Si}_{3}$ などの脆い化合物層中の 微小な割れやボイドなどの欠陥が生じる割合が高くなるこ と ${ }^{26,27)}$ や、それぞれの物質の熱膨張係数の差に起因する残 留応力の増加 ${ }^{11,28,29)}$ などが原因として考えられている。

黒鉛、炭化ケイ素およびサイアロン接合体でそれぞれ破 断形態が異なった理由は次のように考えられる。すなわち、 $\mathrm{Ti}$ 添加量が少ない場合は、いずれの供試材においても、Ti 添加量の増加にともなって、供試材の成分とろう材中の活 性金属である Ti が反応することにより、界面反応層が接合 界面において連続的に形成され、せん断強度は増加する。 黒鉛およびサイアロンでは Ti 添加量 1.7 mass\%、炭化ケイ 素では 2.3 mass\% でせん断強度は最大值を示した。また、 炭化ケイ素およびサイアロンでは、それ以上の $\mathrm{Ti}$ 添加量 では、せん断強度は逆に低下したのに対して、黒鉛では強 度低下は生じなかった。Table 3 に参考值としてそれぞれ の供試材と界面反応層を構成している化合物相の曲げ強度 を示す。黒鉛の場合では、界面反応層に対して黒鉛の強度 が著しく低いため、厚膜の界面反応層が形成されても黒鉛 母材破断となるので、過剩な Ti 添加量においても接合強度 の低下は生じない。炭化ケイ素の場合では、界面反応層で ある $\mathrm{Ti}_{5} \mathrm{Si}_{3}$ と炭化ケイ素の強度が近い值であり、 $\mathrm{Ti}_{5} \mathrm{Si}_{3}$ が厚 膜化することで界面反応層 $\left(\mathrm{Ti}_{5} \mathrm{Si}_{3}\right)$ の強度が低下した結果、 
スマートプロセス学会誌

Table 3 Flexural strength of experimental materials used in this work and interfacial reaction compounds ${ }^{30-36)}$.

\begin{tabular}{cc}
\hline Material & Flexural strength /MPa \\
\hline Graphite (IG-11) & 39 \\
\hline $\begin{array}{c}\text { Silicon carbide } \\
\text { (RE-SiC) }\end{array}$ & 100 \\
\hline Sialon (SAN-2) & 980 \\
\hline $\mathrm{TiC}$ & 1100 \\
\hline $\mathrm{TiN}$ & 265 \\
\hline $\mathrm{Ti}_{5} \mathrm{Si}_{3}$ & $94-255$ \\
\hline
\end{tabular}

Ti 添加量が過剰な場合は界面破断となって接合強度が低下 する。そして、サイアロンの場合では、界面反応層である $\mathrm{Ti}_{5} \mathrm{Si}_{3}$ がサイアロン母材に対して強度が低いことから、い ずれの Ti 添加量においても界面破断を呈すると考えられ、 過剰な Ti 添加量においては炭化ケイ素の場合と同様に界面 反応層 $\left(\mathrm{Ti}_{5} \mathrm{Si}_{3}\right)$ の厚膜化によって接合強度が低下する。また、 $\mathrm{Cu}_{3} \mathrm{Ti}$ の強度は参考值が得られなかったが、全ての供試材 の破断面において $\mathrm{Cu}_{3} \mathrm{Ti}$ は超硬合金側のろう材上からのみ 検出され、 $\mathrm{Cu}_{3} \mathrm{Ti}$ での破断が生じていないことから、比較 的強度が高いと考えられる。

\section{3 その他のセラミックス材料への展開}

本稿では、黒鉛、炭化ケイ素およびサイアロンについて、 ろう材中の Ti 添加量が界面構造および接合継手強度に及ぼ す影響を報告した。これらで得られた知見を元に、ダイヤ モンド、立方晶窒化ホウ素およびアルミナなどへの適用検 討を行っている。ダイヤモンド／超硬合金は、Fig. 17 に 示す通り、良好な外観の接合継手が得られ、 Ti 添加量 1.7 mass\%のろう材を用いた場合では、せん断試験においてダ イヤモンド母材破断を呈し、接合強度として $115.9 \mathrm{MPa}$ が 得られた。また、アルミナでは $91.2 \mathrm{MPa}$ の接合強度が得ら れている。

\section{4. 今後の展開}

本レーザブレージングの今後のさらなる展開として、 レーザ照射中の接合体の加熱・冷却過程の温度変化や応力 変化の有限要素法による熱伝導および応力解析を進めてい る。Fig. 18 に数值解析によって得られた応力分布図例を示 す。接合部端部での応力集中現象や残留応力に起因する割 れの発生を再現可能である。本稿で用いた供試材において は、炭化ケイ素では Fig.18 に示す応力集中箇所において割 れが認められ、黒鉛およびサイアロンでは認められず、こ れらは熱膨張係数や破断強度などの材料物性によって整理 が可能であった。今後は残留応力の低減に向けた継手設計、 接合体の大寸法化、レーザ熱源の最適化などが求められて いる。
第 3 巻 第 1 号（2014 年 1 月）

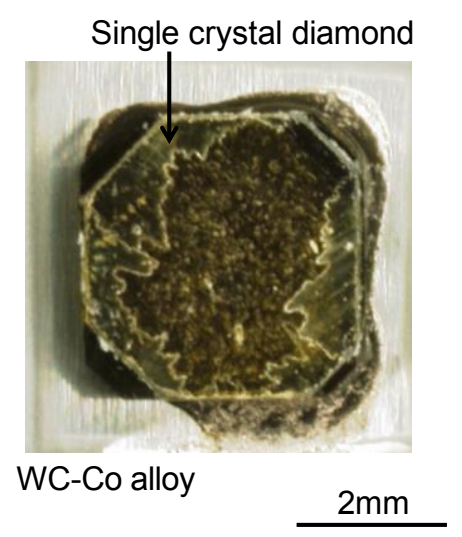

Fig. 17 Appearance of laser brazed joint of single crystal diamond/WCCo alloy.

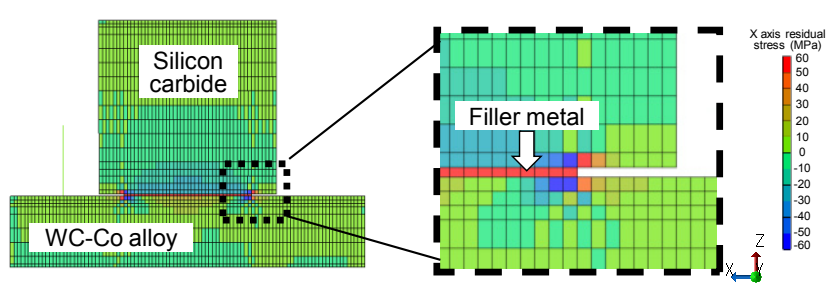

Fig. 18 Computed $X$ axis residual stress distribution on $X-Z$ cross section around filler metal of laser brazing specimen.

\section{5. まとめ}

新しいレーザブレージング法のセラミックスと超硬合金 の異材接合への適用を行い、ろう材中の活性金属元素であ る $\mathrm{Ti}$ の添加量が接合強度および界面構造に及ぼす影響なら びにセラミックスの母材の種類による影響を検討した結果 を紹介した。本稿が当該研究分野の一助となれば幸いであ る。

\section{引用文献}

1) 佐久間健太 : “セラミックス材料学”、海文堂出版株式会社 (2004).

2）小松和蔵、佐多俊之、守吉佑介、北澤宏一、植松敬三：“セラ ミックス材料科学入門（基礎編、応用編）”、株式会社内田老 鶴圃新社 (1980).

3）社団法人日本金属学会：“金属便覧”、丸善株式会社 (2000).

4）村上陽太郎、亀井清、山根壽巳、長村光造：“金属材料学”、 株式会社朝倉書店 (2004).

5) 田中俊一郎：セラミックス、25-3 (1990) 200-204.

6) 馬場大三、澤田知昭：パナソニック電工技報、59-1 (2011) 1724.

7) Y. V. Naidich, V. S. Zhuravlev, I. I. Gab, B. D. Kostyuk, V. P. Krasovskyy, A. A. Adamovskyy and N. Yu. Taranets, J. Euro. Ceram. 
Soc., 28 (2008) 717-728.

8) F. Moret and N. Eustathopoulos: J. Physique 4, 3 (1993) 1043-1052.

9) 松波弘之：“半導体 $\mathrm{SiC}$ 技術と応用”、日刊工業新聞社 (2003) 第 8 章.

10) 柴柳敏哉：溶接学会誌、79-7 (2010) 27-33.

11) G. M. Liu, G. S. Zou, A. P. Wu and D. K. Zhang: Mater. Sci. Eng. A, 415 (2006) 213-218.

12) H. K. Lee and J. Y. Lee: J. Mater. Sci., 31 (1996) 4133-4140.

13) Y. Zhu, Y. Wang and X. Zhao: Trans. Chin. Weld. Inst., 32-6 (2011) 81-84.

14) J. Zhang, Y. M. He, Y. Sun and C. F. Liu: Ceram. Inter., 36 (2010) 1397-1404.

15) 中田一博：溶接技術、52-11 (2004) 126-130.

16) 才田一幸、西本和俊：溶接技術、51-6 (2003) 92-98.

17) 才田一幸、西本和俊：溶接技術、57-6 (2009) 56-66.

18) Y. Sechi, A. Takezaki, T. Matsumoto, T. Tsumura and K. Nakata: Mater. Trans., 50-6 (2009) 1294-1299.

19) Y. Sechi, T. Tsumura and K. Nakata: Mater. Des., 31 (2010) 20712077.

20) Y. Sechi and K. Nakata: Trans. of JWRI, 39 (2010) 340-342.

21) Y. Sechi, K. Nagatsuka, K. Nakata: J. Phys.: Conference Series, 379012048 (2012) 1-10.

22) K. Nagatsuka, Y. Sechi, Y. Miyamoto and K. Nakata: Mater. Sci. Eng. B, 177 (2012) 520-523.

23) K. Nagatsuka, Y. Sechi and K. Nakata: J. Phys.: Conference Series, 379-012047 (2012) 1-9.
24) 永塚公涁、吉田昇一郎、瀬知啓久、中田一博：接学会論文集、 31-1 (2013) 94-100.

25) J. F. Elliott and M. Gleiser, "Thermochemistry for Steelmaking 1 Addison-253”, Wesley (1960).

26) 中尾嘉邦、西本和俊、才田一幸、大石忠美：溶接学会論文集、 11-1 (1993) 142-148.

27) 中尾嘉邦、西本和俊、才田一幸、大石忠美：溶接学会論文集、 11-2 (1993) 294-300.

28) Y. M. He, J. Zhang, C. F. Liu and Y. Sun: Mater. Sci. Eng. A, 527 (2010) 2819-2825.

29) Y. Liu, Z. R. Huang and X. J. Liu: Ceram. Inter., 35 (2009) 34793484.

30) 黒鉛 (IG-11) 製品カタログ、http://www.toyotanso.co.jp/Products/ Special_graphite_detail.html

31) 炭化ケイ素 (RE-SiC) 製品カタログ、http://www.ngk.co.jp/ product/industrial/fireproof/carbide_data_01.html

32) サイアロン (SAN-2) 製品カタログ、http://ebw.eng-book.com/pdf s/49ef1914f9a72667ac25edaffa36b949.pdf

33) 井関考善：核融合研究、62-3 (1989) 175-184.

34) 森山実、鎌田喜一郎、小林義一：日本セラミックス協会学術 論文誌、99-4 (1991) 286-291.

35) J. Li, D. Jiang and S. Tan: J. Euro. Ceram. Soc., 22 (2002) 551-558.

36) R. Mitra: Metall. Mater. Trans. A, 29A (1998) 1629-1641. 